\title{
Stefan Lux (1888-1936): A calculated suicide before the Second World War
}

\author{
Michael Berkowitz \\ University College London
}

The man and his dramatic mission: a brief biography

His name and final deed are little known or recalled. Stefan Lux, a Jewish journalist born in Malacky, Hungary (present-day western Slovakia) in 1888, and naturalized in interwar Czchoslovakia, shot himself during a session of the League of Nations in Geneva 3 July 1936. The purpose of his suicide, as was commonly understood, was to call attention to the inhumane treatment of Germany's Jews under the Nazis. Lux, as an aspiring actor, filmmaker, and journalist, had met and worked with some prominent people, including the illustrious theatrical and film director, Max Reinhardt and the actor Rudolph Schildkraut. But Lux never became famous, attracting scant attention before his suicide. His obscurity was not, however, due to any lack of effort.

Lux's father was a solid, middle-class notary, who moved his family down the road from Malacky to Bratislava in the early twentieth century, where Stefan graduated from secondary school. He went on to study law in Budapest and duly qualified for the bar, but found the practice of law "unsatisfying." ${ }^{1}$ Lux believed he was destined for more creative pursuits. Relocating to Vienna, he studied acting, heading to Berlin in 1911 to join the Deutsches Theatre company, considered one of the world's finest. Lux also wrote poetry, publishing the miniature Liebeslieder, with calligraphy and illustrations by Ida Berisch, ${ }^{2}$ and Meine Lieder, under the pseudonym Peter Sturmbusch. ${ }^{3}$ Some of his poetry was adapted as song lyrics (as Peter Sturmbusch). ${ }^{4}$ He collaborated with Max Reinhardt on Don Juans Liebeslied (Lovesong): romantische Komödie in vier Akten, ${ }^{5}$ but the play Reinhardt staged on Don Juan (1912) was written by Carl Sternheim. ${ }^{6}$

In 1913 Lux joined the cast of Vienna's Neue Wiener Bühne (theatre company), but this was interrupted by the outbreak of the Great War. He was commissioned an officer in the Royal Hungarian 
Honvéd, an infantry regiment and was wounded in battle. Betty Sargent, in one of the few detailed studies of Lux, states that "the only 'negative' mark on his army record was the official disapproval of his liberal tendency to fraternize with the soldiers under his command." ${ }^{7}$ After the armistice Lux returned to Berlin and established the Sozial-Film documentary company, which struggled to become established and never quite got off the ground. Alarmed by the burst of antisemitism that accompanied the Central Powers' defeat and the creation of the Weimar Republic, Lux aspired to produce films to combat the spurious charges leveled against the Jews. Lux directed Sozial-Film's first movie, Geretchtigkeit (Justice), starring Rudolph Schildkraut, "which portrayed the centuries-long struggle of Jews to preserve their integrity despite exclusion and expulsion from one place to another." Shildkraut also was in the circle of Max Reinhardt. "The Berlin premiere", Sargent writes, "was scheduled for March 1920, but after the Kapp Putsch — an attempt by the armed antidemocratic forces to overthrow the republican government - the financial backers, frightened by the tense political atmosphere, withdrew their support, and Justice was never shown." Even more ominously, this was apparently the only film to have been released by the company, and the sole film in which Lux earns a credit ${ }^{8}$--despite being identified in the Encyclopaedia Judaica as a "film producer." 9

Compelled to give up on this endeavor, Lux worked for other studios but none of his own projects seem to have come to fruition. He turned, then, "to political journalism as a staff member of Berlin's radical weekly, Weltbühne", which was edited, during Lux's association, by Siegfried Jacobsohn, Kurt Tucholsky, and finally, Carl von Ossietzky. Although left-wing and ardently anti-fascist, Die Weltbühne was enmeshed with the arts scene and high-brow intellectuals, which might have inspired Lux to establish a similar organ that would be more down-to-earth. "In 1932 he announced plans to publish an inexpensive magazine designed for the 'little man,' a home for informative articles written in a popular style but with a liberal point of view." This never got off the drawing board. With Hitler's advent to power, "in early 1933 Lux moved hurriedly with his wife and son to Czechoslovaka," where he held citizenship. While not penniless, the family arrived in Prague "without furniture or belongings, 
which their Berlin landlord had seized." ${ }^{10}$

Lux's intention was "to produce plays along the lines of the films he had envisioned in Berlin", ${ }^{11}$ but the best he could manage in Prague were performances of the Jüdische Kammerspiele, which has been described as a "local amateur and semiprofessional" ensemble. ${ }^{12}$ The plays were vehicles to defend Jewish rights. Although his byline was infrequent, at best, Lux also had press credentials for the Prager Presse, the newspaper founded by Tomas Masaryk, edited by Arne Laurin. This was his situation--poor prospects and an unstable livelihood--when he arrived in Geneva for the League meeting in which he planned and carried out his suicide. ${ }^{13}$ "Alarmed by the world's indifference to Nazism's and Fascism's increasing influence, Lux decided to sacrifice his life to alert humanity. On July 3, 1936, he shot himself in the press gallery of the League of Nations Assembly Hall in Geneva, after leaving warning letters to Anthony Eden", the British Foreign Secretary, "and other leaders." ${ }^{14}$

As much as the latter statement is a reasonable summary, it does not do justice to either the highly specific nature of Lux's suicide or the complicated responses to it. In retrospect, the situation for German and Austrian Jews in 1936 would become more dire and lethal in the coming years. Few sensed that anything akin to what would emerge as the Holocaust, or even the horrors of the Anschluss (March 1938), followed by the "November Pogrom" (9 and 10 November 1938), were in store. For Lux, however, it appeared that the situation — at a time that is perceived ninety-years later as relatively tranquil in the Nazi onslaught--was unprecedented in post-emancipation western Europe and becoming more threatening. German Jewry was, for all intents and purposes, ghettoized, and the suffocation historian Marion Kaplan identifies as "social death" was well underway. ${ }^{15}$ We shall see, though, that Lux was deeply disturbed and distressed by Nazism, beyond the evolving antisemitism in the Third Reich and injuries inflicted upon its Jews per se. He had a plan in which he anticipated the consequences of his action. He was so confident of the reaction to his suicide that he was oblivious to the extent it was uncontrollable and a gamble. Nevertheless, the story of why he staged his demise, and his forecast regarding the changes that would be effected, deserve closer inspection. 
$\underline{\text { Recalling the toll of Jewish persecution and discrimination before the Holocaust }}$

In hindsight, it is difficult to fathom that for those who lived through the period between 1933 and 1939, it was nearly unimaginable that anti-Jewish persecution might become far worse. ${ }^{16}$ There is no doubt that official acceptance of antisemitism, with the Nazis' assumption of power, signaled to thousands of Jews that they were outcasts and that their lives would become unbearable. As much as historians hesitate to admit such reservations, it is incredibly difficult to state unequivocally the reason why someone would take his or her own life. Even if suicide notes, or multiple letters are prepared (as did Lux), this does not always provide a full account, or capture what triggered the irrevocable decision. There probably were highly personal aspects of his situation that we will never know.

To the extent that Lux was noticed for his suicide, and remembered in retrospect, the intentions behind his act have been, to various degrees, mischaracterized. Revisiting his case helps to cast a light on the reactions to Nazism and Nazi antisemitism in particular, outside of Germany, as well as on the League of Nations and international politics during the interwar period. With careful forethought, Lux murdered himself exactly at a moment when the League was about to take up the problem of "statelessness." Few of the press comments concerning his death recognized this, with some important exceptions: the New York Times, and Gerechtigkeit, a weekly of Vienna, to be explored in depth below.

\section{$\underline{\text { Reconsidering the history of the League of Nations }}$}

The focus on the League of Nations, surrounding the strange case of Lux, reveals a critical aspect of its history that has not been thoroughly discussed — despite the appearance of highly-praised academic studies of the institution, ${ }^{18}$ and international relations generally, in the period after the Great War. ${ }^{19}$ While there are always historical blind spots, this omission seems rather odd—-because as early as 1951 Hannah Arendt brought the concept of "statelessness" to the world's attention. ${ }^{20}$ In sum: this is the problem that Lux believed he could rectify through his suicide on 3 July 1936, at the very meeting 
place of the League of Nations. "Though this be madness, yet there is method in 't." (Shakespeare's Hamlet, 2:2) Lux was aware that many observers would dismiss his act as a symptom of insanity and self-obsession, but this could be overcome, he wagered, by carefully explaining his motives to a variety of public figures. To the extent that scholars beyond Hannah Arendt have dealt with the problem of Jews and statelessness, comment largely centers on the failed Evian conference of July $1938^{21}$--which was almost two years after Lux's act. The even more belated Bermuda conference occurred in $1943 .{ }^{22}$ Statelessness was, to be sure, an urgent problem in the summer of 1936, and on the eve of war, Bernard Wasserstein has shown that a shocking number of Jewish refugees throughout 1939 were in "so-called 'camps."'23 A more in-depth study of 'the method to Lux's madness' also affords us an opportunity to compare and contrast it with the chilling phenomenon of Jewish suicide in Nazi Germany, and Jews and suicide more generally.

After raising, and solving the problem of statelessness, Lux's priority was to shake the League of Nations, and for that matter, the world, from its tacit acceptance of Nazi propaganda. Emil Ludwig believed that Lux had recognized, in Prague, that the Nazis had radically interfered in Czechoslovakian political and cultural life, to the harsh detriment of the Jews, which was similar to what drove David Frankfurther to murder a Nazi emissary in Davos, Switzerland in the same year. ${ }^{24}$ As a film enthusiast Lux was unusually attuned to how the Nazis had been using media to shape and spread their message, and to make themselves appear both normalized and unthreatening. He believed, though, that in less than three years Hitler had completely reformulated the idea of what Germany was (a country without Jews, or where Jews were supposed to be ghettoized and dispossessed) situated an abstract Jewish enemy as center-stage, and espoused that all of past and present (non-Jewishly inflected) German culture, by its nature, served the ideal of Aryan racial superiority. The rest of the world, in Lux's eyes, only saw fit to believe that Hitler was making Germany great again, as opposed to recognizing that he radically distorted national norms, with the result of excluding and demonizing Jews as antithetical to Germans and all forms of Germanness. He hoped that his death would not only awaken people to the 
daily horrors and indignities faced by Germany's Jews, but to shake them out of their stupor in failing to register that the German nation and its culture was not as Hitler and the Nazis claimed.

\section{Correcting an earlier perspective on Lux}

The lead question posed by Betty Sargent, apparently the sole investigator who has elaborated and published on the case of Lux, is 'why did this brazen act fail to have much effect?' With all due respect to an earnest, and largely reliable retelling of "The Desperate Mission of Stefan Lux" by Sargent, I strongly disagree with her core assertion that "Almost no one believed him."25 "Unfortunately," she writes: "Lux's mission was misrepresented by some, dismissed by others, and forgotten by nearly all." 26 I adamantly concur, on the other hand, that Lux has indeed been forgotten — but this has little to with whether or not he was "believed." The principle aim of her article is to draw attention to Robert Dell, who was "the Geneva correspondent of the Manchester Guardian" at that time. Dell, Sargent reports, who was one of her own mentors, "had received Lux's letter to his paper, to which was attached a copy of the long letter that Lux had attached to [Anthony] Eden", then Britain's Foreign Secretary. "These documents led Dell to conclude that Lux had been driven to suicide by much broader international concerns than those announced. And as the author of Germany Unmasked $(1934)^{27}$ — a stinging indictment of the Nazi regime and its plans for foreign conquest—Dell identified with these concerns." Inspired by what she knew personally as Dell's "astute judgment", ${ }^{28}$ Sargent juxtaposes "Dell's message regarding Lux", an "unforgettable introduction to Stefan Lux" ${ }^{29}$ which the Manchester Guardian did not publish, with the blithe dismissal of the event by the League of Nations. To be sure, Dell recognized that Lux's suicide was neither an act of a "deranged refugee", as some press reports maintained, ${ }^{30}$ nor exclusively derived from his obsession with "the plight of the Jews in Germany"31_ but that Hitler and Nazism represented a grave threat to all of humanity and Nazi Germany was girding itself to undermine world order and security. ${ }^{32}$

Both Sargent and Dell were correct. Germany's menace to Europe and beyond was indeed on Lux's mind and his fear was shared by Dell. But at the moment of his suicide, an outright attack on 
neighboring or far-flung countries was not imminent. This longer-range prediction was part of the motive for Lux's suicide, but does not fully explain the setting and, especially, the timing.

\section{$\underline{\text { Reconstructing the context }}$}

Sargent's detailed reconstruction of Lux's life is for the most part commendable, as is her esteem for Dell. But she vastly underestimates and undervalues the extensive comment on the suicide - in major and minor organs of the press, especially the Jewish papers. These articles, along with others, contradict her claim that Lux was not taken seriously. Many of these were translated into Spanish and assembled into a pamphlet compiled in Argentina in 1937, after the international PEN conference held there. That meeting included protests against fascism by the noted Yiddish writer H. Leivick (18881962) and the German pacifist, Carl von Ossietzky (1889-1938), apparently read in absentia. ${ }^{33}$ At least one of the articles excerpted in this publication (by Arnold Hahn) was published, in its complete form, as a separate pamphlet. ${ }^{34}$

Jews and suicide, beyond Durkheim's assumptions and Jewish apologetics

There is another perspective on this tragedy that Sargent did not fully grasp: the climate of despair that already engulfed German Jews, and those who closely followed their situation. For those who experienced the German-Jewish situation in the 1930s and 40s, suicide among them was a widespread phenomenon, which touched a great number of people even outside of Central Europe and the expanding Nazi orbit. ${ }^{35}$ Despite Emile Durkheim having included Jews in his foundational work on the history of suicide, ${ }^{36}$ most of the scholarly, and social science treatments of suicide (until now) tend to marginalize or ignore minority populations, which often experience relatively high rates of suicide. Durkheim's notion that "the tendency to suicide among the Jews is very slight", and that "of all religions, Judaism counts the fewest suicides" is highly dubious, ${ }^{37}$ even omitting the horrors of Nazism. "Before the Nazis came to power," Christine Hartig writes, Jewish suicides in Germany "were explained as being caused by personal misfortunes and blamed by some on assimilation and alienation from Judaism." ${ }^{38}$ Sophisticated approaches to the internalization of stereotypes and prejudice on 
diverse planes reveal that suicidal thoughts among minority groups are quite widespread yet difficult to assess. $^{39}$

Upon the armistice that concluded the Great War, Jews were cast as responsible for Germany's loss of the war through the purported "stab in the back." ${ }^{40}$ They also were charged with orchestrating the burdensome and humiliating Versailles Treaty along with the various crises involving food distribution and public welfare from 1918 until the early 1920s. Jews were far from immune to feeling the sting of this incessant barrage, even if it was largely resisted by the Social Democrats of Weimar Germany. The economic crisis of the war's aftermath, coming to a head in the panic of 1923 , certainly exacerbated this anxiety. The actual precariousness of most German Jews was in sharp contrast to the general non-Jewish views that Jews had either come through unscathed, or emerged wealthier in the wake of the crises. "In the 1920s there was a general increase in the number of German suicides," Christine Hartig writes, "but the drastic rise in the suicide rate for Jews was a source of particular unease." $^{41}$

Christian Goeschel, the most authoritative scholarly guide through the dark story of Jewish suicide in Weimar and Nazi Germany, does not comment on Lux. But his work is helpful for situating Lux's act and its reception. "In the Third Reich," Goeschel asserts, "suicide became a routine phenomenon among German Jews," which extended "beyond the confines of the Third Reich to exile, to Auschwitz, and to later times." Anyone with German-Jewish friends, professional contacts, or family was likely to have known someone who had taken his or her own life. Many were socially prominent, even famous — but soon forgotten. Some six months after Lux's suicide, Ernst Lubitsch, a German Jew who was already at home in Hollywood before Nazism took power, wrote to Hal Wallis, a producer now best remembered for Casablanca. Rather abruptly, Lubitsch began the message by stating "Paul Graetz, the German Jewish actor who played a part in one of your pictures, Mr Cohen Takes a Walk, died last week under the most tragic circumstances." Clearly, he had taken his own life. "Paul Graetz," Lubitsch informed Wallis, who might not have been aware of Graetz's stature in Weimar Germany, 
"used to be one of the most prominent and most popular actors in Berlin, and if there ever was a victim of Hitlerism - it was Paul Graetz." ${ }^{2}$ Among the earliest group of Jews targeted by the Nazis were those who worked in newspapers and the entertainment industries. ${ }^{43}$ Entire bureaucracies were created for the purpose of staffing these areas with Nazi-sanctioned 'Aryans.' "He had to leave his house and home in Berlin and seek refuge in a foreign land. His widow, who bravely followed him into exile, is now left penniless and in dire want." The immediate problem, in light of these specific cases, was to help provide for survivors, who usually were in desperate straights. "Several of his old friends have started a collection for Mrs. Graetz, but unfortunately these friends are exiles themselves and not in a position to contribute as generously as they would like to." With subtle pressure, Lubitsch concluded: "If you feel inclined to join his friends in this very worthy cause by sending your check, I would deeply appreciate it." 44

"While most Jews committed suicide in private," Goeschel writes, "people sometimes wrote suicide notes to make their desperate situation public. They rightly assumed that the police and other Nazi institution would read their suicide notes. Contrary to their intentions, Jewish suicides did not shock Nazi authorities, so Jewish suicides were not political weapons." What Lux intended, however, was precisely the opposite: he imagined that his suicide would become an immediate cause célèbre, a lever, or a sort of weapon. "During the deportations," which would commence years after Lux's deed, "suicide was above all an action to keep control of the self and to evade the deportations and what came after."45 Goeschel has built on the work of Konrad Kwiet and Helmut Eschwege, who were among the initial scholars to see Jewish suicide as an unusually conspicuous feature of the Jews' experience under Nazism, and their framework for analysis also helps to illuminate Lux's motive and aspirations. Kwiet and Eschwege interpreted Jewish suicide as a gesture of non-conformity to Nazism that others preferred to valorize as resistance. Above all, we must recall that suicides of German Jews, after the Nazi takeover of power in 1933, quickly grew to "epidemic proportions"—rendering Lux's suicide less remarkable and memorable that it otherwise may have been. In the immediate wake of the "November 
progrom" of 1938 there were up to five hundred suicides. ${ }^{46}$ Yet as much as it is important to place Lux's act within the vast sea of suicides of Weimar and Nazi times, it also is critical to explore why he thought that the response to his public act would be different than those of all the others, and why it was perpetrated at a specific time and place.

The date, early July 1936, is furthermore significant because it was a month before the Berlin summer Olympics, held 1-16 August 1936. While public antisemitic humiliation ceremonies, economic boycotts against Jews (beginning in 1933), and the Nuremberg Laws of 1935 were far from secret, the Nazis made a concerted effort not to allow their anti-Jewish and anti-Roma campaign to seem violent, or, at least not as central as it was to Nazi policy in the months leading up to the Olympics. Certainly the Nazis had been worried about the Jewish-led (but deeply contentious) boycott campaign against the Berlin Olympics over human rights abuses. Among Jewish athletes and sporting bodies there were fierce debates about whether they should attempt to participate, and there was a lack of clarity about whether or not their inclusion would be allowed by Nazi officials. Famously, several (but not all) anti-Jewish signs were taken down, especially in and around Berlin, so as not to raise concerns about the stigmatizing of Jews. In addition to the apparent success of downplaying antisemitism and anti-Roma sentiment, the Nazis also were, overall, tremendously successful in obscuring their military buildup and intention to dominate both their supposed internal enemies and enemy nations. ${ }^{47}$ Lux's letters to various officials-Secretary-General of the League, Joseph Avenol; Anthony Eden, Foreign Secretary of United Kingdom; King Edward VIII; the Manchester Guardian, The Times of London, and Geneva journalist Paul du Bochet ${ }^{48}$--reveal his grave concern that the world had been lulled into thinking that a strong Germany was desirable for world stability.

The Jewish religious motif of martyrdom, as discussed extensively by Kwiet and Eschwege, probably does not apply to the vast majority of largely secular German Jews who killed themselves. ${ }^{49}$ This framework, however, may help to comprehend Lux. Although he was offering himself as martyr, he was doing to with the express objective of influencing a specific matter on the agenda of the League 
of Nations. The idea that he was sacrificing himself for the cause of Jewry was not necessarily admirable or impressive to the Jews themselves, and this also may help to account for his near total erasure from history. It is the combination of the timing and venue of his suicide, which comprises a foremost reason for recalling and investigating the case of Stefan Lux_-beyond simply memorializing "an unsung hero". 50

Arnold Hahn's pamphlet and other published comment

To recast this event, it is helpful to focus attention on a particular, substantial response to Lux's suicide, excerpted in the Spanish publication. This is the previously mentioned 31-page pamphlet by Arnold Hahn, under the auspices of the Czechoslovakian League versus Antisemitism, which elaborates on other rationales for Lux's alarm and despondence. ${ }^{51}$ Among Hahn's emphases is that Lux was mortified in recognizing that the world did not seem to comprehend the extent to which, already by 1936, the Nazis had totally coordinated and controlled the media being produced in the country, and that seemed to be accepted, largely uncritically, by most non-Jews. Lux correctly discerned that the center of the Nazi Weltaschauung was the demonization and vilification of the Jews. ${ }^{52}$ To him this was especially abhorrent due to the overwhelmingly constructive roles Jews had played in German culture and economic development and their unquestionable loyalty to the nation. His own efforts to counter the Nazis with documentary film and political theatre had had little influence. It was not, therefore, simply a parochial concern for Jews that drove Lux - but his perception that this was one of the keys to the irrational, duplicitous edifice supporting Nazism. It was only growing in strength and respectability. So Lux believed he had to take a drastic action to both forestall Germany, and signal that the Jews trapped in Germany and beyond its borders must be granted refuge. This dimension of Lux's story, his warning about the manipulation of media and its impact, strikes a particularly chilling note in our own day. 53

Lux's act certainly was noticed in the international press. He was not generally painted as a madman. There is little reason, therefore, to contend that he was disbelieved as a spokesman for the 
defense of German Jewry. In comparison, the self-immolation of Shmuel Zygielbojm, in London, in 1943, in the midst of what would come to be seen as the Holocaust, elicited far greater concernalthough most of this emanated from the Bund, the political current of which he was a part. ${ }^{54}$ Zygielbojm had been a prominent opponent of Jewish acquiescence in the creation of a ghetto in Warsaw, who succeeded in escaping to the west. In a recent event, in London, to commemorate the $75^{\text {th }}$ anniversary of Zygielbojm's death, there was no mention of Lux. ${ }^{55}$

\section{Accuracy and insight from the New York Times}

Perhaps not surprisingly, the New York Times account of Lux's suicide holds up quite well. The page-four headline reads: "SUICIDE SHOT RINGS AT LEAGUE SESSION; Czech Journalist Startles the Delegates by Firing Bullet Into Chest on Floor. PROTESTS FOR REICH JEWS. Planned Act to Call Attention to Their Plight, Says Letter Found in His Briefcase." The article, dateline Geneva, July 3 [1936], continues:

Tragedy in concrete form intruded itself into this gathering of the League of Nations today. It concerned directly neither the Ethiopian issue nor the League's future, but it did indicate the despair of a large section of the world's population over the failure of League bodies to act positively on any question. It also was indicative of the tension that prevails here in Geneva.

The morning session of the Assembly was enduring the translation of a long speech by the Spanish delegate, with most seats vacant, when from the space below and to the left of the rostrum a shot was heard. A man was seen standing up with one arm raised, He shouted something then fell. The interpreters stopped translating and Premier Paul van Zeeland of Belgium, who was presiding, asked if there was a doctor among those present. Dr. Phillippe Roy of the Canadian delegation hurried forward and gave first aid to the wounded man. At hospital he died late tonight of an internal hemorrage after having protested all day that he did not want to live.

\section{A Prague Newspaper Man}


Inquiry has shown that he was Stefan Lux of Chechoslovak nationality, who was born in Vienna of Jewish parents. He was 48 years old. Prior to 1933 he had lived for twenty-five years in Germany, as a member of the staff of the Weltbuehne, a Berlin radical weekly. The advent of the Nazis to power drove him out and he had since lived in Prague, working for the Prager Presse, the daily he was representing at this Assembly meeting. He had a wife and a 12-year-old son and was far from penniless. ${ }^{56}$

The New York Times correspondent assumed was that it was not penury that drove Lux to suicide. The writer probably took for granted that the suicides of other German Jews was chiefly the result of having lost their wealth or the basis of their livelihoods. The fact, though, that Lux himself seemed to be a stable member of the middle class does not mean that he was untouched by economic insecurity or deep apprehension. ${ }^{57}$ Among the German-speaking community in Prague, he felt that Jews were victims of increasing hatred and discrimination. Certainly he believed, as did Dell, that Hitler's appetite included part or all of Czechoslovakia. ${ }^{58}$ There was good reason, therefore, for Lux to be anxious about his financial prospects, as well as the situation of his parents. As was indicated by Dell's view of Lux, Stefan Lux saw Hitler's claims of disinterest in expansion and conquest as a boldfaced lie. It was not simply that Lux was protesting the inhumane treatment of Germany's Jews. He believed that the Nazi's aggression was imminent (although extremely unlikely to occur that summer, because of the Olympics), and that the fortunes of himself and others were already seriously threatened. Sensing that Austria would go the way of Germany, Lux surmised that his father would be in difficult straits. As a notary he might have had increased business from Jews seeking official documentation to facilitate emigration. But he also might lose his position, overall, because the Nazis' first moves, in Germany, had included banning Jews from the civil service. Lux also was aware that his friends and colleagues in journalism and the arts would be pressured out of their jobs in short order.

The New York Times report continued: "He left his seat in the press gallery this morning and 
somehow got down to the floor, where there is a bench for press photographers. Near the close of the morning session he took out an automatic pistol. Many delegates saw him, but supposed what he held was a flashlight pistol. They saw him stand up. Then to their surprise he shouted something and fired the pistol into his chest." ${ }^{59}$ Lux's decision to shoot himself in the area of the hall for press photographers was intentional. Because he wished his suicide to draw the maximum amount of attention, he thought that by killing himself among the photographers, he would be photographed, which would add to the already dramatic story. This did not happen. There are no known photos of Lux from the League hall. It also seems that the gunshot did not cause great alarm-because it had come from the press section — where flash bulbs routinely 'exploded' when photos were taken in low light.

Confusion through a publicity attempt

Lux's positioning of himself in the photographers' gallery also led to some confusion in how his story was told. Some of the press reports mis-identified him as a photographer. This misperception was compounded by an attempt of the "Jewish Information Bureau" to generate publicity about the event. In their reporting of the story, and dispatching the news to outlets they encouraged to feature the event, Lux was called a "press photographer." ${ }^{60}$ This was inaccurate, and might have confounded attempts by reporters to gain background for the story. The generic nature of the press report circulated by this office, which was simply repeated in a number of Jewish press articles, may have led them to conclude that there was little more to be said beyond the fact of his self-sacrifice for the sake of the Jewish cause.

"Miss Helen Kirkpatrick, an American girl attached to the Geneva Research Center," was apparently an informant of the unnamed New York Times correspondent. She "was in the secretariat enclosure near by and seems to have been the only person who observed him closely. She says what he shouted was: 'C'est le dernier coup.' (This is the last blow.) Afterward, when he lay wounded on the floor, he kept repeating: 'Avenol, Avenol-mappe' briefcase.)" ${ }^{61}$ The tragedy of Lux's suicide is compounded by 
the grotesque scene as he lay on the floor of the press gallery, repeating the name "Avenol"--imploring whoever was nearby to speed his briefcase to the Secretary-General of the League of Nations, Joseph A. C. Avenol, a Frenchman who is little remembered in diplomatic history. While he wished to force his plea upon the highest official of the body, which seems logical, it reveals the extent to which Lux's sense of the high-mindedness of the League of Nations, and the character of its leader, was far off the mark. ${ }^{62}$ He thought that Avenol would instantly inspect the briefcase, read the letter addressed to him immediately, and that it would influence his handling of the assembly's next order of business. We have no idea when Avenol read the letter, but he did not thoroughly peruse the briefcase contents before the agenda of the League was resumed. Nothing was said on the floor of the assembly acknowledging the tragedy in even the most basic sense. In any case, Lux's deed or words had no impact on what transpired.

\section{Lux's misplaced faith in Joseph Avenol}

There is no evidence that Avenol was ever outspoken as an antisemite, but in hindsight it is clear that he was "a person of the extreme right." ${ }^{63}$ Lux was certainly not alone is misjudging Avenol: he was "something of a chameleon, presenting himself in a favorable light to every person he met."64 But sympathy for Jews played no part in Avenol's attitudes, as he professed to have taken no side in the Dreyfus Affair ${ }^{65}$ - a defining episode in French politics. Despite having sought the leadership of the League of Nations, he did not believe that there was broad scope for action on the part of either his own office or the organization in general. He registered little resistance to the aggression of Italy and Germany and was 'hostile' to Poland. ${ }^{66}$ It also did not help that he was "exceedingly lazy" and 'neither honest nor straightforward ${ }^{67}$ - he brought little energy or industriousness to the position. Lux's faith in Avenol to take charge, and do the right thing, was either an extreme case of wishful thinking, or the mistaken belief that the head of a body such as League could not be so listless. Sargent informs us that in his letter to Avenol, Lux took pains to assert that he did not intend to disrupt or disrespect the workings of the League of Nations. ${ }^{68}$ Little wonder that after resigning his post, Avenol sought— but 
was not granted - an attempt "to secure a position in the Vichy administration", ultimately to serve Nazi rule. ${ }^{69}$ The alacrity with which Lux's body and appeal was scoured from the hall of the League might have been among the more swift, decisive actions in all of Avenol's tenure, which has been described by his astute biographer, James Barros, as "betrayal from within." While the structure of the League of Nations did not grant sweeping power to its Secretary General, Barros convincingly argues that Avenol could have done much more with his authority in order for the League to realize its aims.

The New York Times furthermore asserted that the later examination of Lux's briefcase "showed it contained letters addressed to Joseph A. C. Avenol, the League's Secretary General; King Edward VIII, the Times of London and the Manchester Guardian. The letter to Avenol said in effect that he intended to kill himself publicly at this last meeting of the Assembly to draw attention to the plight of Jews in Germany. The other letters are supposed to be of the same purport." 70 The next line of the article reveals the most transparent motive for Lux's act: "A conference is in progress here discussing the legal status of refugees from Germany." (emphasis added) In the language of the time, although "refugees" might have included others besides Jews, it overwhelmingly was meant to indicate Jews. The "conference" referred to, is most likely a committee meeting of the league. "It opened yesterday and got to work today, but naturally it has not yet made any considerable progress. It hopes to devise a system whereby those refugees now without passports or legal protection may obtain some travel and working papers enabling them to remain the countries in which they have sought refuge and to avoid expulsion, to which they are now liable." (emphasis added) The statement that "This is the nearest approach to a reason for connecting Mr. Lux's state of mind with the present assembly meeting" is indeed penetrating. ${ }^{71}$ His chief objective was to assure that stateless refugees would be protected by the League of Nations.

The New York Times article wished to stress the thought behind his deed. "There is no doubt, however, that his act was premeditated. Last night he paid his bill at the pension where he had been staying and settled all his other obligations. He told the pension proprietor to watch for an important 
development today connected with himself. The proprietor took this as a joke. 'Are you then going to be elected President of the Czechoslovak Republic?' he asked. 'No,' replied Mr. Lux seriously, 'but this development will be sensational."'72 ${ }^{72}$ That was indeed his desire, but the response cannot even be judged 'sensational' in the marginal Jewish fold.

Gerechtigkeit and Irene Harand

The Viennese weekly Gerechtigkeit, along with the New York Times, is among the few publications that situated Lux's suicide in the context of the deliberations and acts of the League of Nations. "In Geneva," an unsigned editorial asserted,

there is always talk of sanctions, of Abysinia, of Danzig, and sometimes also of Locarno.

Concerning the inhuman treatment that has made the Jews suffer in the Third Reich, nothing. There was once, in Geneva, a debate on the subject of the Jews, and this, thanks to the demand registered by a German Jew in Upper Silesia. This Jew had the happiness of living in a province where there is the right of national minorities guaranteed by the law of nations. Then, there was one day a disturbing letter from the former High Commissioner for Refugees, [Ramsay] McDonald. And then, for a long time, nothing. A few days ago, a shot.

A Jewish journalist had been killed in the meeting room of the [League of Nations]. in Geneva. It was a shot from desperation. The Jewish journalist Stefan Lux chose death, through the sacrifice of his own life, to deflect the attention of the world toward the horrific tragedy of the German Jews.

The deliberations were interrupted, and upon reopening, the president declared: "This fact has no relation with the debates of the Assembly of the [League]." Do these words agree with the facts? The sacrifice of Stefan Lux has no relation with the deliberations of the League of Nations. In Geneva there is no talk of German Jews. ${ }^{73}$

The writer believed the suicide of Stefan Lux would send a "chill down the spines of the elegant statesmen" that would inspire them to think differently about the plight of the Jews. This was all too hopeful. $^{74}$ 
Historian Bruce Pauley writes that this newspaper, Gerchtigkeit, offered "a startling contrast to the continuing antisemitism of most Austrian newspapers." It was edited by Irene Harand, a Roman Catholic woman in her mid-30s "who took up the fight against Nazism and antisemitism soon after the Nazi electoral success in Germany in September 1930. After giving a number of anti-Nazi speeches and publishing, at her own expense, a brochure in March 1933 entitled So oder So? Die Wahrheit über den Antisemitismus (Either This or That? The Truth about Antisemitism), she founded Gerechtigkeit in August of the same year. By December 1936, it had twenty thousand readers in thirty-six countries. A year later it was being published in French, Czech, and Hungarian, in addition to German." ${ }^{75}$ It is worth reflecting on Irene Harrand and what has been referred to "the Harand Movement", as it offers insight into why the Lux case dissolved into oblivion. Due to the fragmentation of different Jewish groups, and the reticence of some official Jewish bodies to make common cause with non-Jewish Nazi opponents, erecting a significant challenge to Nazi expansion was never realized.

A brief history provided by Yad Vashem relates that "[w]hen the Nazis annexed Austria in March 1938, Harand was on a lecture tour in England. She decided not to return to Austria, but to immigrate to the United States together with her husband. In America, she continued to fight Nazism and Antisemitism. She also used her connections in Europe to help save fugitive Jews, and continued to support the Austrian and Polish Zionist youth movements. In cooperation with Bnei Brith and Stephen Wise, she helped Austrian Jews get visas to the United States, eventually arranging entry papers for more than 100 Austrian Jews. In 1943, she founded the Austrian Institute (Österreichische Institut) in New York, an organization that helped Austrian Jewish refugee authors and artists living in America to find work in their fields." ${ }^{76}$ Pauley aruges, however, that Jewish organizations might have been more forthcoming in seeking and appreciating the assistance of Harand and her family, as opposed to viewing her with unwarranted caution, if not suspicion, that they did not share the same objective. ${ }^{77}$

The case of Lux would be mentioned again in the New York Times sixty years later in a review of an "Exhibit in Geneva Recalling Era of the League of Nations" by Victor Lusinchi-but cited as an 
significant omission. "The crack of the pistol shot," Lusinchi wrote, "could be heard in the press workroom behind the press gallery. Menachem Kahany, ${ }^{78}$ a observer for Jewish organizations who was sitting in a public gallery opposite Mr. Lux, recalls that 'attendants carried him out so quickly that few people in the hall realized just what happened."' Among other critical moments "overlooked", according to Lusinchi, was "what many considered to be a major political achievement of the League", that is, "the accord that created the first international peacekeeping force." 79

It seems that from his particular vantage point, as a man immersed in journalism and the arts, Lux feared that all of the possible defenses the Jews had utilized before 1933 were no longer viable. They were under assault by the entirety of the arts and cultural apparatus in Germany. Certainly there were personal factors involved in Lux's decision as well. This case, though, illustrates how far a political actor may go when faced with the prospect that the group to which he belongs is being lethally threatened. $^{80}$

\section{Context and comparisons}

Yet another of the reasons why Lux is not well remembered is because he was not uniformly lauded as a hero in the Jewish press. Moment, a Yiddish daily in Warsaw, said expressly that he was no hero, that staging an act in the so-called "palace of nations" was "no more than a comedy, a charade, a joke, a bloody mockery." ${ }^{81}$ His "symbolic suicide," the Jewish paper of Geneva reported, amounted to nothing more than another tragedy among others. ${ }^{82}$ The Yidishe shtimme (Kovno) situated Lux among the saints and martyrs who ultimately sacrificed themselves for their love of mankind and faith in the efficacy of their actions. But the writer pointed out that the choice of David Frankurter (1909-1982) to murder the Nazi Wilhelm Gustloff in Davos in 1935, was also a "human" form of protest. ${ }^{83}$ Emil Ludwig, perhaps the most popular German-Jewish author between the wars, ${ }^{84}$ wrote an entire book in defense of Frankfurter's crime, The Davos Murder. Rather than reacting to an expressly personal tragedy or affront, Frankfurter killed Gustloff as a specific effort to forestall or turn back Gustloff's centrality in the attempt to transform Switzerland into a vassal state of National Socialism--which he 
had been pursuing with great vigor, aggressiveness, and success. ${ }^{85}$

Ludwig asserted that he felt compelled to write about Frankfurter from a "sense of justice, in February 1936, immediately after the murder, as soon as the historical significance of the deed became apparent." In his legal training, thirty years previously, "at the Berlin seminary of my distinguished German teacher Franz von Liszt, I studied the problem of homicide committed under stress of powerful emotion. When I took my degree as Doctor of Laws at Breslau, my thesis was devoted to the same topic. Subsequently I considered the question in a number of historical portraits. At that time, in imperial Germany, we were not taught that right meant no more than what was advantageous to Germany. Our instructors, being citizens of the world, based criminal law, as they based civil law, upon moral principles; while Lizst, in his lectures and writings, was careful to explain why German law provided for a mitigation of punishment when the offender had been grievously wronged. In the world of today, as contemporaries, we are able to consider such a case in its historical setting." ${ }^{86}$ Toward the book's conclusion, "after a consideration of parallel instances, we cannot but come to the conclusion that our judgment of David Frankfurter's offense must be on all counts more lenient than our judgment of the [political] murders committed by Conradi, [Salomon] Schwarzbard, and Teilirian--who were aquitted." ${ }^{87}$ Ludwig, not surprisingly, wrote the lengthy poem that served as the epigraph to Arnold Hahn's memorial book for Lux. In addition to being sympathetic to Lux, Ludwig praised him for his expression of ardent Jewish solidarity, across the borders of time and space. ${ }^{88}$ One of the saddest ironies is that Lux's act itself might have deflected attention away from the matter at handstatelessness.

Few if any suicides, which have not followed the deaths of others, have resulted in dramatic changes in state policy. Assassinations, however, sometimes do result in momentous changes. ${ }^{89}$ What if Stefan Lux had fired at Avenol before killing himself? What if Avenol's successor, Sean Lester, had assumed office in 1936, instead of 1940? There was a world of difference between Lester's commitment to the ideals of the League of Nations compared to his predecessor. Lester, in contrast to Avenol, was deeply 
concerned with the fate of Europe's Jews. ${ }^{90}$ It is impossible to say if there would have been a difference, and Lux probably never contemplated anything along the lines of an assassination. But certainly the suicide of Lux would be read differently if his weapon had been brandished against Avenol, rather than him trusting Avenol to take up the cudgels after his own demise.

The initial version of this paper was presented at the conference Suicide, Society, and Crisis: An International Symposium funded by the Wellcome Trust, held at the Humanities Research Institute, University of Sheffield, 18 May 2018. I wish to thank Dr Julie Gottlieb for her interest and support. I also wish to thank the anonymous readers of this article for their extremely helpful comments and suggestions. Research for this project was supported by a fellowship from Yad Vashem, summer 2016.

${ }^{1}$ Betty Sargent, "The Desperate Mission of Stefan Lux," in The Georgia Review, Vol. 55/56, Vol. 55, no. 4/Vol. 56, no 1 (Winter 2001/Spring 2002), pp. 187-201, especially 196-7; Stable URL: http://www.jstor.org/stable/41402132; accessed:13-02-2018 09:12 UTC.

2 Peter Sturmbusch [Stefan Lux], Liebeslieder, illustrations and calligraphy by Ida Berisch (Wien: Carl Kogegen, 1921).

3 Peter Sturmbusch [Stefan Lux], Mein Lieder (Wien: Carl Konegen, 1917). There is some question of the year of publication, as one catalogue entry lists the date as 1911.

${ }^{4}$ Otto Siegl, Gesänge nach Teten von Peter Sturmbusch, op. 10 (Wien, L. Doblinger, 1925);

${ }^{5}$ There is apparently only one copy of this work extant, held at the State University of New York at Binghamton.

${ }^{6}$ See John L. Styan, Max Reinhardt (Directors in Perspective) (Cambridge: Cambridge University, Press, 2008), 138.

${ }^{7}$ Sargent, 197.

8 "The German Early Cinema Database", see http://drc.uni-koeln.de/companies/view/847 [accessed 2 October 2018]. 
${ }^{9}$ Yehuda Reshef, "Lux, Stefan," in Encyclopaedia Judaica, eds. Michael Berenbaum and Fred Skolnik, $2^{\text {nd }}$ ed., vol. 13, Macmillan Reference USA, 2007, 275. Gale Virtual Reference Library, http://link.galegroup.com/apps/doc.CX2587512891/GVRL?u=ucl ttda\&sid=GVRL\&xid=1edadfcd. Accessed 13 Feb. 2018.

10 Sargent, 197.

11 Ibid.

12 Jarka Burian, Modern Czech theatre: reflector and conscience of a nation (Studies in theatre history \& culture) (Iowa City: University of Iowa Press, 2000), p. 30.

13 Sargent, 197.

${ }^{14}$ Yehuda Reshef.

${ }^{15}$ Marion Kaplan, Between dignity and despair: Jewish life in Nazi Germany (New York and Oxford: Oxford University Press, 1999).

${ }^{16}$ One of the more striking illustrations of seeing the period prior to the Holocaust per se as the worst of possible worlds, see Gerd Korman, Nightmare's fairy tale: a young refugee's home fronts, 19381948 (Madison, WI and London: University of Wisconsin Press, 2005).

${ }^{18}$ Susan Pedersen, The guardians: the League of Nations and the crisis of empire (Oxford: Oxford University Press, 2015).

${ }^{19}$ Carole Fink, Defending the rights of others: the Great Powers, the Jews, and international minority protection, 1878-1938 (Cambridge and New York: Cambridge University Press, 2006).

${ }^{20}$ For a recent assessment, see David Weissbrodt, "Stateless Persons," in The Human Rights of NonCitizens (Oxford: Oxford University Press, 2008), available at http://www.oxfordscholarship.com/view/10.1093/acprof:oso/9780199547821.001.0001/acprof9780199547821-chapter-4 [accessed 29 June 2018]. 
${ }^{21}$ Henry Feingold, The Jewish people in America: A time for searching: entering the mainstream 1920-1945 (Baltimore and London: Johns Hopkins University Press, 1992), 229-30; Diane Afoumado, Indésirables : 1938, la conférence d'Evian et les réfugiés juifs (Paris: Calmann-Lévy, 2018).

${ }^{22}$ Ibid., 233, 242, 260.

${ }^{23}$ Bernard Wasserstein, On the eve: the Jews of Europe before the Second World War (New York: Simon \& Schuster, 2012), 387.

${ }^{24}$ Emil Ludwig, "In memoriam Stefan Lux," epigraph to Arnold Hahn, Vor dem Augen der Welt! Warum starb Stefan Lux? [Real Name: Schmuel Mosche Ben Awrohom]. Sein Leben, seine Tat, seine Briefe (Prag: Cechoslovakische Liga gegen den Antisemitismus, 1936), Jewish National Library, Jerusalem.

${ }^{25}$ Betty Sargent, "The Desperate Mission of Stefan Lux," in The Georgia Review, Vol. 55/56, Vol. 55, no. 4/Vol. 56, no 1 (Winter 2001/Spring 2002), pp. 187-201; Stable URL:

http://www.jstor.org/stable/41402132; accessed:13-02-2018 09:12 UTC.

${ }^{26}$ Ibid., p. 188.

${ }^{27}$ Robert Dell, Germany unmasked (London: Hutchinson, 1934).

${ }^{28}$ Sargent., p. 192.

${ }^{29}$ Idid., pp. 191-2.

${ }^{30}$ Ibid., p. 191.

${ }^{31}$ Idid., p. 190.

${ }^{32}$ Ibid., p. 191.

${ }^{33}$ Porqué se mató el periodista Stéfan Lux: apuntes para las historia de un mártir del siglo XX.

[Buenos Aires]: Columna, [1937]. I wish to thank my colleague at the University of Texas, Professor Naomi Lindstrom, for sending me a copy of this rare volume. 
${ }^{34}$ Arnold Hahn, Vor dem Augen der Welt! Warum starb Stefan Lux? [Real Name: Schmuel Mosche Ben Awrohom]. Sein Leben, seine Tat, seine Briefe (Prag: Cechoslovakische Liga gegen den Antisemitismus, 1936), Jewish National Library, Jerusalem.

${ }^{35}$ See, e.g., Wout Ultee, Frank Van Tubergen, and Ruud Luijks, "The unwholesome theme of suicide: forgotten statistics of attempted suicides in Amsterdam and Jewish suicides in the Netherlands for 1936-1943," in Dutch Jews as Perceived by Themselves and by Others, eds., Chaya Brasz and Yosef Kaplan (Leiden: Brill, 2001), 325-523.

${ }^{36}$ Emile Durkheim, Suicide: A Study in Sociology, trans. John A. Spaulding and George Simpson, ed. George Simpson (London and New York: Routlege, 2006).

${ }^{37}$ Idid., 18, 121.

${ }^{38}$ Christine Hartig, "'Conversations about taking our own lives—oh, a poor expression for a forced deed in hopeless circumstances!' Suicide among German Jews 1933-1945," in Leo Baeck Year Book, Volume 52 (2007): 264; 247-265.

${ }^{39}$ See Gina Philogene, Racial identity in context: the legacy of Kenneth B. Clark (Washington, D.C.: American Psychological Association, 2004).

${ }^{40}$ George S. Vascik and Mark Sadler, eds., The Stab-in-the-Back Myth and the fall of the Weimar Republic: A History in Documents and Visual Sources (London and New York: Bloomsbury, 2016). ${ }^{41}$ Hartig, 250.

${ }^{42}$ Ernst Lubitsch to Hal Wallis, February 24, 1937, Hal Wallis papers, f. 2249, in Wallis, Hal, personal correspondence, Motion Picture archive, Beverly Hill, CA. Added to this tragedy is that Graetz also had appeared in the notorious Nazi antisemitic movie, Jud Suss. The generally reliable IMD (movie database) relates that Graetz died of a stroke, but "in tributes to well-known personalities suicide was not always mentioned.", Hartig, 252 
${ }^{43}$ Alan Steinweis, Art, Ideology, and Economics in Nazi Germany: The Reich Chambers of Music,

Theater, and the Visual Arts (Chapel Hill, NC: University of North Carolina Press, 1996).

${ }^{44}$ Ernst Lubitsch to Hal Wallis, February 24, 1937, Hal Wallis papers, f. 2249, in Wallis, Hal, personal correspondence, Motion Picture archive, Beverly Hill, CA. Added to this tragedy is that Graetz also had appeared in the notorious Nazi antisemitic movie, Jud Suss. The generally reliable IMD (movie database) relates that Graetz died of a stroke, but "in tributes to well-known personalities suicide was not always mentioned.", Hartig, 252

${ }^{45}$ Christian Goeschel, Suicide in Nazi Germany (Oxford: Oxford University Press, 2009), 96, 111.

${ }^{46}$ Konrad Kwiet and Helmut Eschwege, Selbsthauptung und Widerstand. deutsche Juden im Kampf um Eixistenz und Menschenwurde, 1933-1945 (Hamburg: Christians, 1984), 197, 202.

${ }^{47}$ David Clay Large, The Nazi Games: The Olympics of 1936 (New York: Norton, 2007).

48 Sargent, 190.

${ }^{49}$ Kwiet and Eschwege, 194-215.

${ }^{50}$ Sargent, 188.

${ }^{51}$ Arnold Hahn, Vor dem Augen der Welt! Warum starb Stefan Lux? [Real Name: Schmuel Mosche Ben Awrohom]. Sein Leben, seine Tat, seine Briefe (Prag: Cechoslovakische Liga gegen den Antisemitismus, 1936), Jewish National Library, Jerusalem.

${ }^{52}$ See Jeffrey Herf, The Jewish enemy: Nazi propaganda during World War II and the Holocaust (Cambridge, MA: Belknap Press of Harvard University Press, 2006).

${ }^{53}$ One of the better analyses of the right-wing's highly dishonest use of media is explored in Steve Almond, Bad Stories (Pasadena, CA: Red Hen Press, 2018).

${ }^{54}$ Isabelle Tombs, "'Morituri vos salutant'—Szmul Zygielbojm's suicide in May 1943 and the International Socialist Community in London, in Holocaust and Genocide Studies, vol. 14, no. 2 (Fall 2000): 242-265. 
${ }^{55}$ Wojtek Rappak, email note to the author, 16 May 2018 09:33. For a description of that event, see $<\underline{\text { https://www.eventbrite.com/e/workshop-the-life-death-and-significance-of-szmuel-zygielbojm- }}$

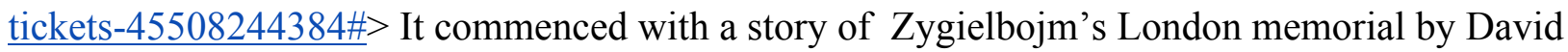
Rosenberg <https://rebellion602.wordpress.com/>, followed by Wojtek Rappak on Zygielbojm's speeches in 1942, then Michael Fleming on the way Zygielbojm tried to make the Labour party take a stance on the news of the Jewish catastrophe coming from Poland in 1942-43 and closed with a short documentary film on Zygielbojm.

${ }^{56}$ In New York Times, July 4, 1936, p. 4.

57 Sargent, 198.

58 Sargent, 188.

${ }^{59}$ New York Times, July 4, 1936, p. 4.

${ }^{60}$ Document collection, Yad Vashem, suicide of the Jewish press photographer, Stefan Lux, Coll. 0.8, Jewish Central Information Office-Amsterdam, Lage der Juden in Deutschland, Antisemitismus (19361938)1 circular from Amsterdam, 4 Juli 1936.

${ }^{61}$ In New York Times, July 4, 1936, p. 4.

${ }^{62}$ James Barros, Betrayal from within: Joseph Avenol, Secretary-General of the League of Nations, 1933-1940 (New Haven and London: Yale University Press, 1969).

${ }^{63}$ Ibid., 18.

${ }^{64}$ Ibid., 21.

${ }^{65}$ Ibid., 15.

${ }^{66}$ Ibid., 161.

${ }^{67}$ British Foreign Office appraisal of Avenol, upon his consideration for the Secreatryship, Barros, 11.

${ }^{68}$ Sargent, 200.

${ }^{69}$ Ibid., 254. 
${ }^{70}$ In New York Times, July 4, 1936, p. 4.

${ }^{71}$ In New York Times, July 4, 1936, p. 4.

${ }^{72}$ In New York Times, July 4, 1936, p. 4.

${ }^{73}$ Bruce F. Pauley, "The Austrian Press and the Third Reich: Contradictory Views from a Neighbor," in Robert Moses Shapiro, Why didn't the press shout? American and international journalism during the Holocaust (New York; Jersey City, NJ: Yeshiva University Press in association with KTAV, 2003), 280-281.

${ }^{74}$ Ibid.

${ }^{75}$ Ibid.

76 "Harand, Irene," Rescue story, Righteous Among the Nations, Yad Vashem: available at http://db.yadvashem.org/righteous/family.html?language=en\&itemId=4015210 [accessed 22 July 2018].

${ }^{77}$ Pauley.

${ }^{78}$ See Jürgen Matthäus, Jewish Responses to Persecution, Volume III, 1941-1942 (Lanham, MD: Rowman \& Littlefield, 2013), 314.

${ }^{79}$ In New York Times, November 16, 1980, p. 16.

${ }^{80}$ Historian Julie Gottlieb is leading an attempt to refocus scholarly attention, concerning suicide, on the political crises of 1938; see "Historian reveals link between suicide and political crisis", in HNN [History News Network], posted September 28, 2018, available at https://historynewsnetwork.org/article/170110 [accessed 4 October 2018].

${ }^{81}$ In Porqué se mató el periodista Stéfan Lux, 27.

${ }^{82}$ Ibid., 28.

${ }^{83}$ Ibid., 27. 
${ }^{84}$ George L. Mosse, German Jews beyond Judaism (Bloomington and Cincinnati: Indiana University

Press and Hebrew Union College Press, 1985), 20, 24-5.

${ }^{85}$ Emil Ludwig, The Davos Murder, trans. Eden and Cedar Paul (London: Methuen, 1937), 49-63.

${ }^{86}$ Ibid., vii-viii.

${ }^{87}$ Ibid., 125.

${ }^{88}$ Hahn, 1.

${ }^{89}$ Dan Ephron, Killing a king: The assassination of Yitzhak Rabin and the remaking of Israel (New York: Norton, 2015).

${ }^{90}$ Paul McNamara, Sean Lester, Poland and the Nazi takeover of Danzig (Dublin: Irish Academic Press, 2009). 